\title{
O CASO MEURSAULT
}

Roberto da Rocha Rodrigues ${ }^{1}$

\section{O Caso Meursault \\ Kamel Daoud \\ tradução de Bernardo Ajzenberg}

São Paulo: Biblioteca Azul, 2016, Objetiva, 165 p.

ISBN: 9788525062024

O livro $O$ caso Meursault é uma narrativa em primeira pessoa cujo tom de queixume retoma, em outra perspectiva, os fatos ocorridos na Argélia no ano de 1942: o assassinato de um homem árabe em uma praia, às $14 \mathrm{~h}$, sob o sol escaldante. 0 olhar do leitor é conduzido por Haroun, que tinha apenas 7 anos quando seu irmão mais velho foi assassinado, restando-lhe apenas sua mãe, já que seu pai desapareceu. A personagemnarradora vai todos os dias se embebedar em um bar de Orã e acaba encontrando, neste estabelecimento, um universitário francês que está na Argélia para pesquisar e escrever sua tese acerca destes acontecimentos.

Kamel Daoud revisita a narrativa escrita por Albert Camus em $O$ Estrangeiro, porém, sob a óptica dos argelinos. Isto significa que, ao reconstituir a obra de Camus, Daoud propõe ao leitor, através de Haroun, que alguns fatos históricos sejam revistos: o período em que a França era colonizadora da Argélia e os movimentos pela independência do país que estavam sob a organização da Front de Libération Nationale e de outros grupos, culminando na Independência da Argélia em 5 de julho de 1962, após 132 anos de colonização francesa.

Cada capítulo de $O$ caso Meursault se contrapõe à narrativa do livro de Camus, isto é, a interpretação de Meursault enquanto narrador de $O$ Estrangeiro versus a compreensão de Haroun, narrador de $O$ caso Meursault, que analisa os fatos (o suposto crime apresentado de forma diferente nas duas obras) e seus desdobramentos décadas depois do ocorrido. Por este viés, Haroun demonstra não perdoar a indiferença com a qual o crime foi cometido e narrado: seu irmão não teve direito à palavra alguma na história de Meursault e sequer foi nomeado, sendo citado apenas como "árabe" ao longo de toda a narrativa. Cabe mencionar que nesse ínterim entre as duas narrativas Haroun declara que nem ele e tampouco seus amigos se identificam assim. Para ele, a palavra "árabe" não identifica nação alguma.

\footnotetext{
${ }^{1}$ Roberto da Rocha Rodrigues é professor licenciado em Letras Português/ Espanhol, pedagogo e, atualmente, aluno do bacharelado em Letras (ênfase em Linguística) da Universidade Federal de São Paulo. Contato: robertorodrigues@usp.br.
} 
Esta atitude do narrador de $O$ Estrangeiro provocou a inquietação de Haroun que viu seu irmão ser coisificado após a morte e nem pôde ao menos enterrá-lo, pois o mar levou seu corpo: "o homem perdeu seu nome, sua vida e seu próprio cadáver em um único dia" (pp. 75-76). A narração de Haroun explicita e amplifica o sofrimento que ele e sua mãe viveram durante décadas, pois todas as mazelas familiares e a instabilidade do país contribuíram para que sua mãe ignorasse a existência do filho caçula e sofresse o luto pela perda do filho mais velho por um período sem prazo para findar-se. Esse sofrimento, por sua vez, tornou-se uma obsessão para a mãe de Haroun, já que ela passou a viver em função da morte de seu filho mais velho, o que inevitavelmente impôs este mesmo processo a Haroun e desencadeou todos os conflitos vividos por ele ao longo da narrativa.

Dito de outra forma, a partir disto o narrador viveu em torno da sombra de seu irmão. Fatos que comprovam esta obsessão são citados no decorrer dos encontros entre o narrador e o universitário francês no bar, tal como sua alfabetização tardia em língua francesa para poder recontar e reler para sua mãe os recortes de jornal que noticiaram a morte de "um árabe", pois nem mesmo os jornais identificaram quem havia sido assassinado.

Por este prisma, temos nesta obra, finalmente, a identificação do desagravado: Moussa. Desta forma, com ironia e ressentimento, Haroun acaba nomeando a todos do bar e do país com o nome de seu irmão: "Eles são milhares arrastando-se por aí desde a Independência" (p. 36). Com este relato, Haroun pretende fazer com que o universitário francês entenda que ao matar Moussa e não o nomear e tampouco lhe dar voz, significa que o mesmo aconteceu com todos os argelinos, pois seu irmão não era "nem visto nem conhecido, apenas morto" (p. 59). Esta escolha por parte de Daoud ao dar vida e determinadas características/ marcas psicológicas ao narrador deixa transparecer, dentre outras possibilidades interpretativas, que há um contraponto importante entre $O$ Estrangeiro e $O$ caso Meursault: as duas obras igualam os argelinos, mas de forma diferente. Enquanto a narrativa escrita por Albert Camus evidencia o fato de os colonizadores franceses não se importarem em identificar e diferenciar os argelinos ao tratar a todos como "árabes", a narrativa de Daoud propõe, então, que todos os argelinos não sejam "árabes", mas que sejam "Moussa", isto é, que o povo argelino compartilha sim de uma unidade social, porém não a apontada pelo narrador de $O$ Estrangeiro, mas a unidade de uma nação na qual os compatriotas sofreram durante a colonização, sofreram novamente durante os movimentos pela independência e continuam sofrendo por injustiças acumuladas desde que o país foi liberto.

No capítulo 8, Haroun faz uma confissão ao universitário: ele matou um homem francês que tentou refugiar-se em sua casa nos primeiros dias da Independência, em uma noite de verão de 1962 por volta das duas horas da manhã. Diferentemente da narrativa de Albert Camus, Daoud identificou, através de Haroun, o francês assassinado: era Joseph Larquais, que possuía parentesco com os donos da casa na qual a mãe de Haroun trabalhava. Este assassinato traz à narrativa um fato real: o Massacre de 5 Julho 
que ocorreu em Orã, em razão do confronto entre muçulmanos e europeus algumas horas antes da proclamação da Independência da Argélia.

Este acontecimento na narrativa evidencia uma dualidade vivida por Haroun: ele se entregou às autoridades locais alguns dias após cometer o crime e, na prisão, foi questionado pela autoridade local do porquê ele não ter participado dos movimentos pela Independência da Argélia, pois se ele tivesse matado Joseph Larquais antes da Independência, seria considerado que havia matado pelo motivo certo. No entanto, matar o francês após a Independência, a partir do dia 5 de julho, seria considerado que o crime foi cometido por Haroun sozinho, isto é, sem envolvimento com os grupos que lutavam pela Independência e, consequentemente, por motivos que não eram tidos como corretos naquelas circunstâncias. Por outro lado, Haroun tinha dado ao francês um destino semelhante ao de seu irmão: matou-o a tiros, às duas horas (mas eram duas horas da manhã), agindo por vingança e com o apoio/ cobrança de sua mãe. Isso fica esclarecido quando, no capítulo 11, o narrador conta que sua mãe havia escolhido aquele roumi para ser punido em virtude de ele adorar se banhar às duas horas da tarde na praia em que Moussa fora assassinado, e ela o via retornando com a pele bronzeada, irradiando felicidade, despreocupação e liberdade todas as vezes em que ele voltava a Hadjout para visitar os Larquais. Na confidência de Haroun, a data em que ele matou o francês era irrelevante: ele matou, sim, pela Independência dele e de sua mãe, pois se libertaram de continuar a viver à sombra da morte de Moussa.

Ao assumir para o universitário que também havia matado alguém, Haroun revela seu anseio por ter um julgamento. De acordo com os pensamentos do narrador, não ser julgado e não ser condenado pelo assassinato de Joseph Larquais era visto como um fato que desqualificaria seu ato e sua vingança, algo que o atingiria por caracterizar o ocorrido pela mesma nulidade da morte de Moussa. Haroun foi solto na manhã do dia seguinte ao desse interrogatório. Todas essas nuances dos pensamentos do narrador salientam os conflitos enfrentados por ele no âmbito pessoal/ familiar e na esfera social: por um lado, havia uma cobrança por parte dele e de sua mãe para elucidar e vingar o crime cometido por Meursault e, por outro lado, havia a cobrança de seus compatriotas para que ele pegasse em armas para libertar a Argélia, já que matar franceses era algo que deveria ter sido feito antes (da Independência).

A narrativa de Daoud consegue levar o leitor a construir mentalmente uma imagem da Argélia durante o período da guerra e das décadas seguintes: como as pessoas se vestiam e se relacionavam, a segregação das pessoas nos bairros que eram divididos em locais onde os europeus moravam e locais onde os muçulmanos moravam, a fé, os conflitos, os movimentos pela independência e, depois, as brigas entre esses movimentos pelo comando do país. Além disso, é possível separar a obra, entre outras probabilidades, 
entre as personagens que aparecem nos relatos do narrador (como a mãe, o irmão, os vizinhos, Meriem, que era a namorada, e tantos outros) e os que fazem parte do cenário: o próprio Haroun, o garçom de origem cabila (vocábulo de origem árabe para designar as tribos berberes do Marrocos e da Argélia), o universitário francês e um homem que frequentava o bar e sempre estava lendo e fazendo recortes de jornais. Destes, podemos destacar o universitário francês, que não foi nomeado, e a personagem emblemática do homem que recortava jornais. Haroun pensava que ele apenas ouvia as conversas, no entanto descobre, no capítulo 14, que se tratava de um surdo-mudo aparentemente tuberculoso, mas que sabia fazer leitura labial.

Uma possível interpretação sobre essas personagens sugere que, em primeiro lugar, a não identificação do universitário francês suscita a visão que os argelinos possuem sobre os franceses, enxergando-os da mesma forma, como se todos fossem um só. Esta postura do narrador também é uma forma de vingar seu irmão utilizando dos mesmos recursos do narrador de $O$ Estrangeiro: neste, Meursault não nomeia o "árabe"; naquele, Haroun não nomeia o universitário francês. Em segundo lugar, o homem surdo-mudo pode representar o abandono do povo argelino na pós-independência: sem voz e sem capacidade de ouvir por estar fechado em seu sofrimento e em seu espaço. Isto pode ter acontecido pelo desfazimento do entusiasmo da Independência e pela quantidade de "Meursaults" que ainda estavam presentes na Argélia.

O narrador, apesar das lamentações e do inconformismo, tem momentos de ironia. Ele fala ao universitário chamando Meursault de "seu herói", mas descontrói essa visão europeia do livro $O$ Estrangeiro e coloca-se como o verdadeiro herói, juntamente com sua mãe. Ademais, Haroun desmente Meursault sobre os motivos que o levaram a cometer o crime, bem como (re)estabelece, em sua versão, as relações entre as personagens de Raymond, descrito por Meursault como um cafetão que estava contrariado com uma puta, e Moussa, o árabe que quer vingar a prostituta. Ao restabelecer quem eram essas pessoas, Haroun diz que nunca se sentiu árabe, pois o árabe "é como a negritude, que só existe a partir do olhar do branco" (p. 74) contrapondo as diferenças entre os valores europeus e argelinos.

Albert Camus e Kamel Daoud pretendem, em suas narrativas, diluir os horrores da colonização feita pela França e, por conseguinte, digerir os duros aspectos que envolveram o processo de Independência da Argélia e seus sentidos para as duas nações. Em outras palavras, Daoud ressignifica a história narrada em $O$ Estrangeiro para um acerto de contas entre o Meursault personagem e Moussa, entre o Meursault narrador e Haroun (também narrador), e entre o Meursault que não chorou no funeral de sua mãe (e foi condenado por isso: sua desumanidade, e não pelo assassinato de um árabe) e o Haroun que viveu ignorado por sua mãe, mas que teve seu destino encaminhado em razão do sofrimento dela, considerando-a uma heroína. 
Por todos estes contrapontos tecidos de modo espelhado ao romance de Camus, $O$ caso Meursault rendeu a Daoud o Prix Goncourt du Premier Roman (Prêmio Goncourt de melhor livro, para um primeiro romance), mas a repercussão desta obra despertou admiração e rechaço: admiração pela qualidade da narrativa ao preencher lacunas não contadas (ou contadas de outra forma) em $O$ Estrangeiro; na Argélia, entretanto, o livro foi rechaçado em razão de ser considerado uma ofensa por, entre outras causas, renunciar a religião deste país e não representá-lo fidedignamente, ademais de, no entendimento de alguns, promover a islamofobia, que tanto tem se propagado na Europa e, atualmente, de maneira mais contundente nos Estados Unidos. Neste sentido, Daoud tem um posicionamento muito forte em relação à imposição da morte a outras pessoas em nome um dogma, seja ele religioso ou político, pois um direcionamento deste tipo vai contra a liberdade do ser humano. Tal postura o aproxima novamente de Camus e de outros críticos ao Islã, como Salman Rushdie que foi duramente criticado por publicar um livro que foi entendido, no Oriente Médio, como uma conduta ofensiva. Em represália a esse livro, foi promulgada uma fatwa, em 1989, pelo líder religioso aiatolá Ruhollah Khomeini. A fatwa em questão decretava a morte de Salman, pois seu livro, segundo o religioso, continha blasfêmias contra Maomé. Deste mesmo modo, Abdelfatah Hamadache emitiu uma fatwa acusando Daoud por apostasia, declarando-o inimigo do Islã e da língua árabe, e conclamando o Estado argelino para condenar o escritor Kamel Daoud à morte.

Outra comparação que nos ajuda a entender essa linha tênue entre a liberdade de expressão e uma suposta ofensa a determinados valores (que muitas vezes é respondida com violência) é a relação entre Camus e Sartre: apesar de serem de esquerda, os dois romperam por Camus defender as ideias como um instrumento de liberdade, enquanto Sartre enveredou para a militância política e, inclusive, apoiou o uso da violência. Desta forma, tanto para Camus quanto para Daoud, uma visão maniqueísta só pode trazer grande prejuízo à liberdade do homem.

Por fim, a publicação de $O$ caso Meursault contribui para a agenda de debates da contemporaneidade ao trazer, juntamente com $O$ Estrangeiro, aspectos como a questão da justiça, da morte, da utopia do caminho único e absoluto proposto por religiões e fatwas (na fé islâmica, fatwas são interpretações com valor de parecer jurídico). Isto significa que tanto a obra de Camus quanto à de Daoud suscitam o debate acerca da liberdade ou do cerceamento dela por regimes políticos e/ou religiosos, além de engrandecer e superestimar os valores de um povo em detrimento de outros povos ou de quem é nascido em determinada tradição e, no entanto, acaba rompendo com ela.

Texto recebido em: 01 de Fevereiro de 2017. Aprovado em: 24 de Março de 2017. 